\title{
Chicken Meat Quality as a Function of Fasting Period and Water Spray
}

\section{Author(s)}

Komiyama CM

Mendes $A A^{2}$

Takahashi SE

Moreira $J^{3}$

Garcia RG ${ }^{4}$

Sanfelice $C^{5}$

Borba $\mathrm{HS}^{6}$

Leonel FR

Almeida Paz $\mathrm{ICL}^{8}$

Balog $A^{5}$

Student of the Post-Graduation Program in Animal Science of the School of Veterinary Medicine and Animal Science, UNESP. Botucatu, SP, Brazil.

2 Professor of the School of Veterinary Medicine and Animal Science, UNESP. Botucatu, SP, Brazil.

3 Professor of the Federal University of Diamantina. Diamantina, MG, Brazil.

4 Professor of the Federal University of Grande Dourados. Dourados, MS, Brazil.

5 Undergraduate student of Animal Science of the School of Veterinary Medicine and Animal Science, UNESP. Botucatu, SP, Brazil.

6 Professor of the School of Agrarian and Veterinary Science, UNESP, Jaboticabal, SP.

Undergraduate student of the School of Agrarian and Veterinary Science, UNESP. Jaboticabal, SP, Brazil.

8 Post-doc fellow of the Department of Animal Production of the School of Veterinary Medicine and Animal Science UNESP de Botucatu, SP, Brazil.

\section{Mail Address}

Claudia M. Komiyama

Departamento de Produção e Exploração Animal

FMVZ/UNESP

18.618-000. Botucatu, SP, Brasil

E-mail: claudiakomiyama@hotmail.com

\section{Keywords}

Broilers, color, meat, $\mathrm{pH}$.

Study funded by Fundação de Amparo à Pesquisa do Estado de São Paulo.

\section{ABSTRACT}

This study aimed at evaluating the effect of different fasting periods and water spray during lairage on the quality of chicken meat. A number of 300 male Ross broilers were reared up to 42 days of age, and submitted to four pre-slaughter fasting periods (4, 8, 12, and 16 hours) and sprayed with water or not during lairage. Deboned breast meat was submitted to the following analysis: $\mathrm{pH}$, color, drip loss, water retention capacity, cooking loss, and shear force. There was a significant effect $(p \leq 0.05)$ of fasting period on meat luminosity was significantly different, with the highest value obtained for 4-hour fasting, whereas no difference was found among the other fasting periods. Meat $\mathrm{pH}$ values were different among fasting periods when birds received water spray, with birds fasted for 4, 8, and 12 hours of fasting presenting lower meat $\mathrm{pH}$ values $(5.87,5.87$, and 6.04 , respectively). The interaction between fasting period and water spray influenced meat drip loss and cooking loss, with birds fasted for $16 \mathrm{~h}$ and not receiving water spray presenting higher drip loss (4.88) and higher cooking loss (28.24) as compared to the other birds. Fasting period affects meat quality, and very short periods (4h) impair meat quality.

\section{INTRODUCTION}

Pre-slaughter management of broilers routinely adopted in commercial farms in Brazil include six to 12 hours of feed withdrawal, water withdrawal after catching, and lairage time of not less than two hours. The aim of feed withdrawal is to reduce carcass contamination by gastrointestinal content during process, and to replenish glycogen reserves in stressed birds, as the meat quality of these birds in lower.

When feed is withdrawn periods shorter than six to seven hours, the digestive tract is still full of feed, and the intestines are enlarged and round at processing, occupying a large part of the abdominal cavity and increasing the probability of gastrointestinal leaking during evisceration (Northcutt, 2000).

In addition to possible contamination of carcasses during processing, fasting duration is directly related to meat quality. Therefore, the knowledge on optimal pre-slaughter conditions of broilers will allow the production high-quality chicken meat, as these factors, in addition to post-slaughter influences, are involved in final meat quality (Mendes, 2001).

According to Moreira (2005), spraying broilers with water during lairage increases meat cooking loss and causes lower shear and water retention capacity. The same author verified that ante mortem stress caused by short fasting periods, no water spray during lairage, and inadequate lairage time, loading and transport are the main factors responsible for PSE meat. 
Komiyama CM, Mendes AA, Takahashi SE, Moreira J, Garcia RG, Sanfelice C, Borba HS, Leonel FR, Almeida Paz ICL, Balog A

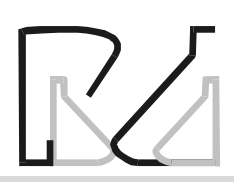

Chicken Meat Quality as a Function of Fasting Period and
Murray \& Rosemberg (1953) reported that glycogen concentration is related to pre-slaughter fasting. Glycogen concentration is lowest when a 16-h fasting period is applied, and increases 33\% between 1 and 10 hours, when birds are re-fed with ground corn. Mellor et al. (1958) evaluated the relation between glycogen and $\mathrm{pH}$, and found that chicken meat with high glycogen concentration presented $\mathrm{pH} 6.2$. therefore, the highest glycogen level was related to more acid meat, as low $\mathrm{pH} 24$ post mortem is related to PSE meat (pale, soft, exudative). According to Kotula \& Wang (1994), glycogen levels decrease as fasting time increases, as they found that zero and 36 hours of fasting resulted in glycogen values at zero hour post mortem) of $7 \mathrm{mg}^{-1}$ and $3.5 \mathrm{mg} . \mathrm{g}^{-1}$, respectively.

Romão (2001) found that broilers not submitted to pre-slaughter fasting presented higher incidence of PSE meat ( $\mathrm{pH}<5.7$ up to 15 minutes) as compared to those submitted to fasting, with a $24 \%$ (12 birds) incidence in Ross broilers and $13.33 \%$ (eight birds) in Cobb broilers. Castro (2006) also asserted that higher PSE frequency is related to very short fasting periods, as there is high glycogen availability in the muscle. Therefore, fasting is related to meat $\mathrm{pH}$ and influences the incidence of PSE in chicken meat.

One of the aims of lairage and water intake of animals during the pre-slaughter period is to allow the re-synthesis of glycogen to increase energy reserves, and therefore to obtain higher meat acidification post mortem. The typical fasting period used in broilers may delay the rate of rigor mortis. As in birds there is rapid development of post mortem chemical reactions, fasting may cause undesirable changes in final meat quality.

Several authors, such as Castro (2006) and Denadai et al. (2002), studied the effect of different fasting periods on carcass yield, offal conditions, live weight loss, and meat quality. However, the relation between the effects of pre-slaughter fasting and water spray on meat quality has not been studied yet. Therefore, the present study aimed at assessing the meat quality of broilers submitted to different pre-slaughter fasting periods, and the use or not of water spray in the lairage.

\section{MATERIAL AND METHODS}

The experiment was carried out at the Poultry Sector of School of Veterinary Medicine and Animal Science (FMVZ), UNESP, Botucatu campus, São Paulo, Brazil. A number of 300 one-day-old male Ross broilers was housed in six experimental pens and reared until 42 days of age, and submitted to equal management and feeding. On day 42, birds were placed in plastic transport crates and transported for three $\mathrm{km}$ to the experimental processing plant of FMVZ, where birds were processed.

Birds were distributed in a completely randomized experimental design in a $4 \times 2$ factorial arrangement consisting of fasting periods $(4,8,12$, or $16 \mathrm{~h})$ vs. water spray with ventilation during lairage (presence or absence), with ten birds per treatment.

After each fasting period, birds were slaughtered, deboned breasts were collected, and $24 \mathrm{~h}$ later the following parameters were analyzed: $\mathrm{pH}$, objective color, drip loss, water retention capacity, cooking loss, and shear force.

Meat $\mathrm{pH}$ was directly measured in the pectoralis major muscle using a pHmetro (Hanna model HI-8314) coupled to a probe electrode (Belden type lanceFAT, model 9239). Readings were carried out 15, 30, and 45 min after deboning, and 1 and 24 h post mortem (Table 3).

Breast fillet color was determined using a Minolta colorimeter, model CR-300, and CIELab system, according to the following parameters: $L^{*}$ (luminosity), $a *$ (redness), and $b *$ (yellowness) (Van Laack et al., 2000).

In order to determine water retention capacity, 2-g meat cubes were placed between two circles of filter paper placed on two glass plates. A $10 \mathrm{~kg}$ weight was placed on the top glass plate for 5 minutes, after which samples were weighed, as the amount of water loss was calculated as the difference between initial and final weights (Hamm, 1960).

Drip loss was determined by keeping breast fillet under conditions that simulate retail sales. Samples were placed on polystyrene trays, covered with permeable plastic film, and stored at $3 \pm 1^{\circ} \mathrm{C}$ for $72 \mathrm{~h}$. Drip loss was calculated as the difference between initial and final weights (Northcutt et al., 1994; Dirinck et al., 1996).

Cooking loss was measured by grilling breast fillet samples on a heated metal plate until internal temperature reached $82^{\circ} \mathrm{C}$, and calculating the weight difference before and after cooking (Honikel, 1987).

Samples used to determine cooking loss were utilized to measure shear force. Meat fibers were placed perpendicularly to the blades of a WarnerBratzler apparatus, according to the technique described by Froning et al. (1978).

The obtained data were submitted to analysis of variance (ANOVA) using SAS (SAS Institute, 1998) 
Komiyama CM, Mendes AA Takahashi SE, Moreira J, Garcia RG, Sanfelice C, Borba HS, Leonel FR, Almeida Paz ICL, Balog A

statistical package. Means were compared by the test of Tukey.

\section{RESULTS AND DISCUSSION}

Table 1 shows the results obtained for meat color $\left(L^{*}, a^{*}\right.$ e $\left.b^{*}\right), p H$, water retention capacity (WRC), drip loss (DL), cooking loss (CL), and shear force (SF). There were significant differences ( $p d \leq 0.05)$ among treatments for color $\left(\mathrm{L}^{*}\right.$ and $\left.\mathrm{a}^{*}\right), \mathrm{pH}, \mathrm{CL}, \mathrm{SF}$, and $\mathrm{WRC}$ values.

Luminosity $\left(L^{*}\right)$ was significantly (pd" 0.05$)$ higher in birds submitted to $4 \mathrm{~h}$ fasting (51.39), but similar in birds fasted for 8,12 , and $16 \mathrm{~h}$ fasting $(46.98,46.31$, and 46.54, respectively). Castro (2006) also observed that $L^{*}$ values decreased as fasting time increased $(6,12$, $15,18 \mathrm{~h}$ ), and that $\mathrm{L}^{*}$ value was 51.43 for $6 \mathrm{~h}$ fasting, whereas there was no significant difference in the other fasting periods. Redness $\left(a^{*}\right)(p d \leq 0.05)$ was significantly different among fasting times, with lower values observed in birds submitted to 4,8 , and $16 \mathrm{~h}$ fasting $(2.51,3.06$, and 3.02, respectively) as compared to $12 \mathrm{~h}$ fasting (3.30). On the other hand, yellowness $\left(b^{*}\right)$ was not influenced ( $\left.p>0.05\right)$ by fasting periods. The higher $L^{*}$ value and the lower $a^{*}$ value in the meat of broilers submitted to $4 \mathrm{~h}$ fasting shows that this period of fasting affects meat color, as compared to the other fasting periods.

A short fasting period (4h), even in the presence of water spray, is not enough to make birds recover from the stress caused by catching, loading, and transport. Therefore, longer fasting periods - of at least 8 hours - are recommended.

Significant interactions ( $p d " 0.05$ ) between fasting period and water spray were observed in terms of $\mathrm{pH}$, drip loss (DL), and cooking loss $(C L)$, and shown in details in Table 2.

There were significant effects of the interaction between fasting period and water spray on $\mathrm{pH}$ measured $24 \mathrm{~h}$ post mortem, as shown in Tables 1 e 2 .
Meat $\mathrm{pH}$ was different among fasting periods only when birds received water spray. Birds fasted for 4,8 and $12 \mathrm{~h}$ presented lower meat $\mathrm{pH}(5.87,5.87$, and 6.04, respectively). In general, meat $\mathrm{pH}$ increased with fasting period. According to Bressan \& Beraquet (2002), two hours of lairage resulted in higher muscle $\mathrm{pH}$ as compared to zero and four hours of lairage, explaining why the establishment of rigor mortis was faster in birds that did not rest or rested for $4 \mathrm{~h}$ than in birds that rested for two hours.

\begin{tabular}{|c|c|c|c|c|c|}
\hline \multirow[t]{2}{*}{ Water spray } & \multicolumn{4}{|c|}{ Fasting period (hours) } & \\
\hline & 4 & 8 & 12 & 16 & \\
\hline \multicolumn{6}{|l|}{$\mathrm{pH}$} \\
\hline$Y e s^{24 h s}$ & $5.87 \mathrm{~b}$ & $5.87 \mathrm{~b}$ & $6.04 a b$ & $6.10 \mathrm{a}$ & 5.97 \\
\hline No & 5.89 & 6.04 & 6.02 & 6.00 & 5.98 \\
\hline Mean & 5.88 & 5.95 & 6.03 & 6.05 & \\
\hline \multicolumn{6}{|l|}{ Drip loss (DL) } \\
\hline Yes & $5.17 \mathrm{a}$ & $5.37 \mathrm{a}$ & $5.11 \mathrm{a}$ & $2.38 \mathrm{Bb}$ & 4.51 \\
\hline No & 4.73 & 3.41 & 3.45 & $4.88 \mathrm{~A}$ & 4.12 \\
\hline Mean & 4.95 & 4.38 & 4.28 & 3.63 & \\
\hline \multicolumn{6}{|c|}{ Cooking loss (CL) } \\
\hline Yes & $28.45 \mathrm{a}$ & $27.38 \mathrm{ab}$ & $29.07 \mathrm{a}$ & $24.31 \mathrm{Bb}$ & 27.30 \\
\hline No & 27.60 & 27.68 & 30.23 & $28.24 \mathrm{~A}$ & 28.44 \\
\hline Mean & 28.03 & 27.53 & 29.65 & 26.27 & \\
\hline
\end{tabular}

Means followed by different small letters in the same row and capital letters in the same column are different $(p \leq 0.05)$ by the test of Tukey.

Meat pH (Table 3) was significantly influenced $(p \leq 0.05)$ by the different fasting period. The lowest values were obtained in the meat samples of birds submitted only to $4 \mathrm{~h}$ pre-slaughter fasting, and there were no significant differences $(p>0.05)$ in $\mathrm{pH}$ (evaluated in different periods) among the remaining pre-slaughter fasting periods (8, 12, and 16 hours). Castro (2006), analyzed meat $\mathrm{pH}$ eight hours after slaughter, also did not detect any effect ( $p>0.05)$ of the different pre-slaughter fasting periods, with $\mathrm{pH}$ values between 5.71 and 5.77 .

Tables 1 and 2 show drip loss and cooking loss as a

\begin{tabular}{|c|c|c|c|c|c|c|c|c|}
\hline \multirow{2}{*}{$\begin{array}{l}\text { Parameters } \\
\text { Fasting(hours) }\end{array}$} & \multicolumn{8}{|c|}{ Quality traits } \\
\hline & $L^{*}$ & $a^{*}$ & $\mathrm{~b}^{*}$ & $\mathrm{pH}$ & $\overline{D L}$ & $\overline{\mathrm{CL}}$ & SF & WRC \\
\hline 4 & $50.39 a$ & $2.51 \mathrm{~b}$ & 3.31 & $5.88^{24 h}$ & 4.95 & 28.03 & $2.28 \mathrm{~b}$ & $58.65 b$ \\
\hline 8 & $46.98 b$ & $3.06 \mathrm{ab}$ & 2.96 & 5.95 & 4.38 & 27.53 & $2.94 \mathrm{a}$ & $90.56 \mathrm{a}$ \\
\hline 12 & $46.31 \mathrm{~b}$ & $3.30 \mathrm{a}$ & 3.35 & 6.03 & 4.28 & 29.65 & $2.98 \mathrm{a}$ & $86.73 \mathrm{ab}$ \\
\hline 16 & $46.54 \mathrm{~b}$ & $3.02 a b$ & 3.19 & 6.05 & 3.63 & 26.27 & $2.96 \mathrm{a}$ & $74.55 a b$ \\
\hline \multicolumn{9}{|l|}{ Water spray } \\
\hline Yes & 47.44 & 3.06 & 3.35 & 5.97 & 4.51 & 27.30 & 2.70 & 80.48 \\
\hline No & 47.63 & 2.90 & 3.06 & 5.98 & 4.12 & 28.44 & 2.87 & 74.76 \\
\hline CV (\%) & 5.49 & 28.67 & 40.94 & 2.52 & 35.55 & 9.72 & 47.11 & 32.62 \\
\hline
\end{tabular}

Means followed by different letters in the same column are different $(p \leq 0.05)$ by the test of Tukey. $L^{*}=$ luminosity, $a^{*}=$ redness, $b^{*}=y e l l o w n e s s$, $\mathrm{DL}=$ drip loss, $\mathrm{CL}=$ cooking loss, $\mathrm{SF}=$ shear force, $\mathrm{WRC}=$ water retention capacity. 
Komiyama CM, Mendes AA Takahashi SE, Moreira J, Garcia RG, Sanfelice C, Borba HS, Leonel FR, Almeida Paz ICL, Balog A

\begin{tabular}{|c|c|c|c|c|c|c|}
\hline \multirow[b]{3}{*}{ Fasting(hours } & \multicolumn{5}{|c|}{ pH values } & \multirow[b]{2}{*}{$\overline{\mathrm{pH}}_{24 \mathrm{~h}}$} \\
\hline & $\mathrm{pH}_{\mathrm{i}}$ & $\mathrm{pH}_{15 \mathrm{~m}}$ & $\mathrm{pH}_{30 \mathrm{~m}}$ & $\mathrm{pH}_{45 \mathrm{~m}}$ & $\mathrm{pH}_{1 \mathrm{~h}}$ & \\
\hline & & & & & & \\
\hline 4 & $6.17 \mathrm{~b}$ & $5.97 \mathrm{~b}$ & $5.88 b$ & $5.86 \mathrm{~b}$ & $5.80 \mathrm{~b}$ & $5.88 \mathrm{~b}$ \\
\hline 8 & $6.37 \mathrm{a}$ & $6.20 \mathrm{a}$ & $6.08 \mathrm{a}$ & $5.93 \mathrm{ab}$ & $5.83 \mathrm{~b}$ & $5.96 \mathrm{ab}$ \\
\hline 12 & $6.33 \mathrm{ab}$ & $6.14 a$ & $5.93 \mathrm{ab}$ & $5.93 \mathrm{ab}$ & $5.91 \mathrm{ab}$ & $6.03 \mathrm{a}$ \\
\hline 16 & $6.37 \mathrm{a}$ & $6.12 \mathrm{ab}$ & $6.07 a$ & $6.01 \mathrm{a}$ & $5.98 \mathrm{a}$ & $6.05 \mathrm{a}$ \\
\hline \multicolumn{7}{|l|}{ Water spray } \\
\hline Yes & 6.32 & 6.14 & 6.02 & 5.97 & 5.90 & 5.97 \\
\hline No & 6.30 & 6.07 & 5.96 & 5.90 & 5.86 & 5.98 \\
\hline CV (\%) & 3.15 & 2.96 & 3.11 & 2.87 & 2.81 & 2.52 \\
\hline
\end{tabular}

Means followed by different letters in the same column are different $(p \leq 0.05)$ by the test of Tukey.

function of pre-slaughter fasting period and water spray at lairage. There was effect of the interaction between fasting period and water spray on drip loss and cooking loss, with birds submitted to $16 \mathrm{~h}$ of pre-slaughter fasting and no water bath presenting the highest drip loss (4.88) and highest cooking loss (28.24) as compared to the other birds. Water spray had no effect ( $p>0.05)$ on drip loss or cooking loss of the meat of broilers submitted to 4,8 , or $12 \mathrm{~h}$ of pre-slaughter fasting $(5.17$ and 28.48, 5.37 and 27.38, 5.11 and 29.07, respectively); however, these values were higher as compared to those obtained in birds submitted to $16 \mathrm{~h}$ pre-slaughter fasting (2.38 and 24.31, respectively). Rasmussen \& Mast (1989) studied the effect of feed fasting on broiler meat composition and quality, and did not find significant differences $(\mathrm{pH}>0.05)$ in cooking loss among fasting periods.

According to Jensen et al. (1998), drip loss is one of the main factors that affect meat quality. It is caused by post mortem myofibril shrinkage due to $\mathrm{pH}$ decrease.

Table 1 shows shear force and water retention capacity values as a function of fasting period and water spray at lairage. These parameters were only influenced $(p \leq 0.05)$ by fasting period. Birds that were fasted for $4 \mathrm{~h}$ presented the lowest shear force value (2.28) and the lowest water retention capacity (58.65), but these were no significant difference $(p>0.05)$ among the other groups (8, 12, and 16h of fasting). Lyon et al. (1991) also studied the effect of preslaughter fasting period on the texture of chicken breast meat, and observed significant influence on shear force, with no fasting resulting in the highest values, whereas fasting for 8 and 16 h promoted similar shear force values ( $p>0.05)$. Castro (2006) did not find any significant difference in meat water retention capacity as pre-slaughter fasting period increased.

The results obtained in the present experiment show that shear force increased as a function of fasting period (after 8h). However, when water retention capacity was evaluated, opposite results were detected, with the lowest value obtained with $4 \mathrm{~h}$ fasting period. In addition, this parameter presented an improvement, represented by an increase, as fasting length increased. However, the fact that breast meat presented lower shear force with $4 \mathrm{~h}$ fasting may be related to the stress caused by this short fasting period. When birds are submitted to stress, their body temperature increases, and muscle $\mathrm{pH}$ decreases due to lactic acid production in the muscle. This situation of low $\mathrm{pH}$ and high temperature in the muscle lead to higher post mortem protein breakdown, with consequent higher tissue water loss, and therefore higher meat tenderness cause by protein breakdown.

\section{CONCLUSION}

Pre-slaughter fasting period influenced meat quality, and very short fasting periods (up to 4 hours) impair meat quality. The results obtained in the present study showed that $L^{*}, \mathrm{pH}$, and other meat quality parameters were negatively affected when birds were submitted to $4 \mathrm{~h}$ fasting, and water spray was not able to ameliorate the effects of this short fasting period. Meat $\mathrm{pH}$ values were different among the evaluated preslaughter fasting periods only when birds received water spray, with birds fasted for shorter periods presenting lower $\mathrm{pH}$ values.

\section{REFERENCES}

Ali ASA, Harrison A, Jensen JF. Effect of some ante-mortem stressors on peri-mortem and post-mortem biochemical changes and tenderness in broiler breast muscle: a review. World's Poultry Science Journal 1999; 55(4):403-414.

Beraquet NJ. Influência de fatores ante e post mortem na qualidade da carne de aves. Revista Brasileira de Ciência Avícola 1999; 1(3): 155-166. 
Komiyama CM, Mendes AA Takahashi SE, Moreira J, Garcia RG, Sanfelice C, Borba HS, Leonel FR, Almeida Paz ICL, Balog A

Berri C. Variability of sensory and processing qualities of poultry meat. World's Poultry Science Journal 2000; 56(3):209-224.

Bressan MC, Beraquet NJ. Efeito de fatores pré-abate sobre a qualidade da carne de peito de frango. Ciência Agrotécnica 2002; 26(5):1049-1059.

Castro JBJ. Efeito do jejum alimentar na qualidade da carne de frangos de corte criados em sistema convencional [dissertação]. Piracicaba (SP): Escola Superior de Agricultura Luiz de Queiroz; 2006.

Denadai JC, Mendes AA, Garcia RG, Almeida ICL, Moreira J, Takita TS, Pavan AC, Garcia EA. Effect of feed and water withdrawal on carcass yield and breast meat quality of broilers. Revista Brasileira de Ciência Avícola 2002; 4(2):101-109.

Dirinck $P$, De Winne A, Casteels $M$, Frigg $M$. Studies on vitamin E and meat quality. 1. Effect of feeding high vitamin E levels on timerelated pork quality. Journal Agricultural Food Chemistry 1996; 44:65-68.

Froning GW, Babji AS, Mather FB. The effect of preslaughter temperature, stress, stuggle and anesthetization on color and textural characteristics of turkey muscle. Poultry Science 1978; 57 : 630-633.

Hamm R. Biochimistry of meat hydratation advances in food research. Cleverland1960; 10(2):335-443.

Honikel KO. Influence of chilling on meat quality attributes of fast glycolysing pork muscles. In: Tarrant PV, Eikelenboom G, Monin G, editors. Evaluation and control of meat quality in pigs. Dordrecht: Martinius Nijhoff; 1987. p.273-283.

Jensen C, Lauridsen C, Bertelsen G. Dietary vitamin E: quality and storage stability of pork and poultry. Trends Food Science Technology 1998; 9:62-72.

Kotula KL, Wang Y. Characterization of broiler meat quality factors as influenced by feed withdrawal time. Journal of Applied Poultry Research 1994; 3(2):103-110.

Lyon CE, Papa CM, Wilson Jr. RL. Effect of feed withdrawal on yields, muscle $\mathrm{pH}$, ad texture of broiler breast meat. Poultry Science 1991; 70:1020-1025.

Mellor DB, Stringer DL, Mountney GJ. The influence of glycogen on the tenderness of broiler meat. Poultry Science 1958; 37:10281034.

Mendes AA. Jejum pré-abate em frangos de corte (revisão). Brazilian Journal of Poultry Science 2001; 3(3):199-210.

Moreira J. Causas da ocorrência de carne PSE em frangos de corte e como controlá-las. In: IV Seminário Internacional de Aves e Suínos; Qualidade da Carne de Aves: Enfoque à Industrialização; 2005; Florianópolis, Santa Catarina. Brasil.

Murray HC, Rosemberg MM. Studies on blood sugar and glycogen on the tenderness of broiler meat. Poultry Science 1953; 37:10281034.
Northcutt JK. Factors influencing optimal feed withdrawal [bulletin 1187]. Georgia: University of Georgia, College of Agricultural and Environmental Sciences; 2000.

Northcutt JK. Extension poultry scientist: factors influencing optimal feed withdrawal duration [cited 2008 jul 31]. Available from: http:/ /pubs.caes.uga.edu/caespubs/pubcd/B1187.htm

Northcutt JK, Foegeding EA, Edens FW. Walter-holding properties of thermally preconditioned chicken breast and leg meat. Poultry Science 1994; 73:308-316.

Rasmussen AL, Mast MG. Effect of feed withdrawal on composition and quality of meat. Poultry Science 1989; 68:1109-1113.

Romão MJ. Carne PSE em frangos: manejo pré e pós abate [dissertação]. Londrina (PR): Universidade Estadual de Londrina; 2001.

Sams AR, Mills KA. The effect of feed withdrawal duration on the responsiveness of broiler Pectoralis to rigor mortis acceleration. Poultry Science 1993; 72(9):1789-96.

SAS Institute. SAS user's guide. Cary, NC; 1998.

Shrimpton DH, Miller WS. Some causes of toughness in broilers. II. Effects of breed, management and sex. Poultry Science 1960; 1: 111-116.

Van Laack RLJM, Liu CH, Smith MO, Loveday HD. Characteristics of pale, soft, exudative broiler breast meat. Poultry Science 2000; 79(7): 1057-1061. 